\title{
Methods for Measurement of Gas Volume of Fruits and Vegetables
}

\author{
Adonal Gimenez Calbo and Amauri Alves Nery \\ CNPH/EMBRAPA. CP 0218, Brasília, DF, CEP 70359-970, Brazil \\ Additional index words. porosity, stress, infiltration, Ipomea batatas, Lycopersicon esculentum, Solanum tuberosum
}

\begin{abstract}
Theory is presented for a differential mass-volume technique to measure non-destructively gas volume $\left(\mathrm{V}_{\mathrm{g}}\right)$ changes, based only on the initial and final masses and volumes of an organ. Volume was measured using Archimedes' principle, but a non-invasive image analysis procedure could be an improvement. A reduction in $V_{\mathrm{g}} d$ uring the ripening of 'Kada' tomato (Lycopersicon esculentum Mill) fruits, and irreversible $V_{\mathrm{g}}$ changes of $0.02,0.29,0.66,1.2$, and $1.3 \mathrm{ml}$ for mature-green fruits compressed by $0,2.5,5.0,7.5$. and $10 \mathrm{~mm}$ for 5 minutes indicates the potential of this procedure. The method was compared with other methodologies using sweetpotato (Ipomea batatas L.) root segments subjected to vacuum water infiltration. The results were similar to the pycnometric method. The gasometric method underestimated $V_{g}$ for roots in which the intercellular air volumes where blocked by the water used for infiltration, and large overestimation occurred with the traditional infiltration technique without correction for water absorption. Absolute $V_{\text {galues }}$ were also estimated by semi-pycnometry (defined as the difference between the organ volume measured by water immersion and the organ volume without $\mathrm{V}_{\mathrm{g}}$ measured with a pycnometer, after its maceration and elimination of gas bubbles with vacuum). Semi-pycnometry applied to tomato and bell pepper (Capsicum annuum L.) fruits, where the use of tissue segments limits the pycnometric method, and in sweetpotatoes, where the gasometric method overestimates $V_{g}$, generated results that were consistently similar to the differential mass-volume method.
\end{abstract}

The network of intercellular air volumes $\left(\mathrm{V}_{\mathrm{g}}\right)$ is the system for the gaseous transport of $\mathrm{O}_{2}, \mathrm{CO}_{2}, \mathrm{C}_{2} \mathrm{H}_{4}$. and other physiologically important gases. The occurrence of $\mathrm{V}_{\mathrm{g}}$ in plant tissues is universal (Sifton, 1945) but highly variable. In leaves. values of $\mathrm{V}_{\mathrm{g}}$ around $25 \% \mathrm{v} / \mathrm{v}$ are typical, but range from $3.5 \%$ in some CAM plants (Smith and Heuer, 1981) to $71 \%$ in Daronicum spp. (Spector. 1956). In bulky organs these spaces are usually smaller. ranging from $\approx 1 \%$ in potato tubers and carrot roots (Jensen, et al.. 1969) to values $>15 \%$ in apple (Baumann and Henze, 1983; Calbo and Sommer, 1987). In roots. it is known that plants with large $\mathrm{V}_{\mathrm{g}}$ are usually more tolerant to flooding (Laan et al., 1989). and $\mathrm{V}_{\mathrm{g}}$ values ranging from $1 \% \mathrm{v} / \mathrm{v}$ in carrot to $>40 \%$ in Rumex maritimus have been observed (Laan et al.. 1989).

The main techniques available to measure $\mathrm{V}_{\mathrm{g}}$ arc gasometric, water infiltration, and the use of Archimedes' principle.

Gasometric techniques usually involve vacuum extraction followed by volumetry (Burton and Spragg, 1950; Calbo and Sommer, 1987; Czersky, 1964; Magness. 1922) or the use of an inert component such as ethane (Cameron and Yang, 1982). The main sources of error for these techniques are due to the solubility of the gases in water.

Water infiltration techniques (Byott, 1976: Smith and Heuer, 1981) usually overestimate $\mathrm{V}_{\mathrm{g}}$ because the cells can absorb water. and the mass increase does not represent $\mathrm{V}_{\mathrm{g}}$. Additionally. the complete infiltration of $\mathrm{V}_{\mathrm{g}}$ may be difficult (Smith and Heuer, 1981).

With techniques based on Archimedes' principle. $\mathrm{V}_{\mathrm{g}}$ is obtained as a difference between the impelling force acting on an organ with and without $\mathrm{V}_{\mathrm{g}}$. Some good techniques arc described by Kushmann and Pope (1968) and Raskin (1983), using nearly identical procedures and calculations. Also. there is the pycnometric method of Jensen et al. (1969) that is much more time-consuming.

Reccived for publication 12 July 1993. Accepted for publication 2 Dec. 1993. Thi investigation was supported by research grants from the Brazilian Scientific and Technological Council (CNPG). The cost of publishing this paper was defrayed in part by the payment of page charges. Under postal regulations. this paper therelore must be herchy marked advertisement solely to indicate this fact.
The destruction of the samples is the major limitation of these techniques.

Although numerous. the techniques used to estimate $\mathrm{V}_{\mathrm{g}}$ in plant organs arc frequently inadequate for some applications. For example, the pycnometric technique of Jensen et a1. (1969) does not count the gas volume of intralocular cavities in fruits such as bell pepper and is not appropriate for succulent organs such as citrus fruits and watermelon, where cutting the organ before introduction in the pycnometer causes immediate changes in $\mathrm{V}_{\mathrm{g}}$. The largest limitation of the available procedures, however, seems to be the practical impossibility to estimate changes over time or between treatments when the variability is high among samples. For most organs. the SD is several times larger than the expected changes of $\mathrm{V}_{\mathrm{g}}$ induced by mild stresses.

In this work, two new techniques are proposed. The first is the differential mass-volume technique that allows rapid and nondestructive measurements of changes in $\mathrm{V}_{\mathrm{g}}$. The differential technique was compacted to other methods and applied to follow changes in $\mathrm{V}_{\mathrm{g}}$ during tomato ripening and to study effects of compression stress. The second is a semi-pycnometric method. where $\mathrm{V}_{\mathrm{g}}$ is estimated as a difference between the product volume measured by water immersion minus its volume without $\mathrm{V}_{\mathrm{g}}$ estimated after maceration with a pycnometer. The applicability of this technique was evaluated in bell pepper and tomato. with locular cavity where the pycnometric method fails, and in sweetpotato, and the results were compared to those obtained with the differential mass-volume technique and other current methods.

\section{Materials and Methods}

Theory of the differential mass-volume method. Gas, liquid, and solid phases are constituents of all plant organs and the organ specific volume $\left(\mathrm{v}_{\mathrm{g}}\right)$ depends on the volume (liter) and mass (kg) of each constituent.

where $\mathrm{V}_{\mathrm{w}}$ is water volume, $\mathrm{V}_{\mathrm{s}}$ is volume of solids, $\mathrm{V}_{\mathrm{g}}$ is gas volume. 
$\mathrm{V}_{\mathrm{o}}$ is organ volume, $\mathrm{M}_{w}$ is water mass, $\mathrm{M}_{\mathrm{s}}$ is mass of solids, and $\mathrm{M}_{\mathrm{o}}$ is the total organ mass.

It is assumed that, in the living tissues, the specific volumes of water $\left(\mathrm{v}_{\mathrm{ew}}\right)$ and solids $\left(\mathrm{v}_{\mathrm{es}}\right)$ remain constant during a measurement and that the gas mass can be disregarded.

$$
\begin{aligned}
& \mathrm{M}_{\mathrm{w}}=\mathrm{V}_{\mathrm{w}} / \mathrm{V}_{\mathrm{ew}} \\
& \mathrm{M}_{\mathrm{s}}=\mathrm{V}_{\mathrm{s}} / \mathrm{v}_{\mathrm{es}}
\end{aligned}
$$

Equation $[\mathrm{I}]$ can be rewritten as

$$
\mathrm{V}_{\mathrm{g}}=\mathrm{V}_{\mathrm{e}}\left(\mathrm{M}_{\mathrm{w}}+\mathrm{M}_{\mathrm{s}}\right)-\mathrm{V}_{\mathrm{w}}-\mathrm{V}_{\mathrm{s}}
$$

According to equations [2] and [3] the variation $\Delta \mathrm{V}_{\mathrm{g}}$ from an initial $\mathrm{V}_{\mathrm{g}}\left(\mathrm{V}_{\mathrm{g} i}\right)$ to a final value $\left(\mathrm{V}_{\mathrm{gf}}\right)$ can be represented by Eq. [5] if $\mathrm{M}_{\mathrm{s}}$ and $\mathrm{V}_{\mathrm{s}}$ remain constant during the assay.

$$
\Delta \mathrm{V}_{\mathrm{g}}=\Delta \mathrm{V}-\Delta \mathrm{M} \mathrm{V}_{\mathrm{ew}}
$$

Eq. [5] can be used to measure the variations in $\mathrm{V}_{\mathrm{g}}$ based on the initial volume $\left(\mathrm{V}_{\mathrm{oi}}\right)$, final volume $\left(\mathrm{V}_{\mathrm{of}}\right)$, and the mass difference AM between the initial mass (M,) and final mass $(\mathrm{M}$,$) of the organ$ under study.

Theory of the semi-pycnometric technique. According to this procedure $\mathrm{V}_{\mathrm{g}}$ is estimated as the difference between the organ volume with its gas content $\left(\mathrm{V}_{\mathrm{o}}\right)$ measured by water immersion and the organ volume without the gas component $\left(\mathrm{V}_{\mathrm{ow}}\right)$, as measured by pycnometry after its maceration and successive vacuum treatments to eliminate all air bubbles.

$$
\mathrm{V}_{\mathrm{g}}=\mathrm{V}_{\mathrm{o}}-\mathrm{V}_{\text {ow }}
$$

The estimate of $\mathrm{V}_{\text {ow }}$ follows from the following equalities:

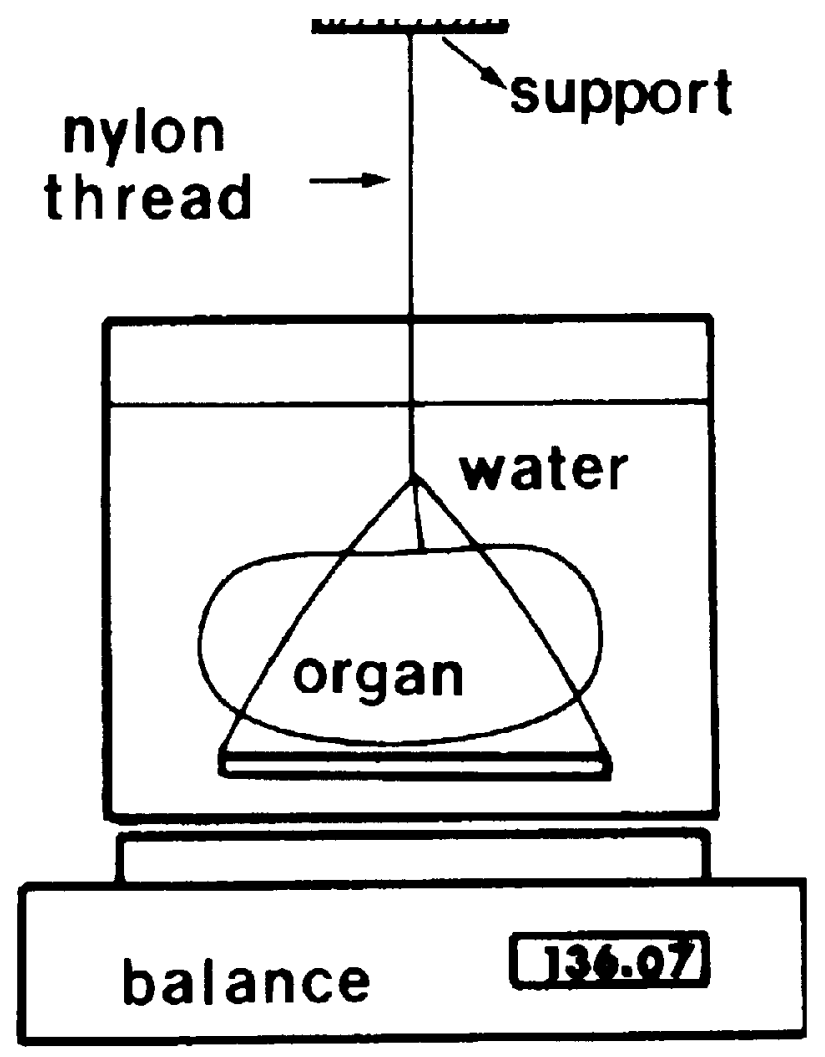

Fig. 1. The balance reading in this equipment is equal to the mass of water displaced by the immersed organ, since the balance is previously zeroed with the aluminum weight hung from the support through a nylon thread. The aluminum weight has the function of keeping the organ immersed without touching the balance.

$$
\mathrm{M}_{\mathrm{h}}=\mathrm{V}_{\mathrm{w}} / \mathrm{V}_{\mathrm{ew}}+\mathrm{M}_{\mathrm{o}}
$$

where $M_{h}$ is the homogenate mass, $M_{o}$ is the organ mass, $V_{w}$ is the water volume added to complete the pycnometer volume, and $\mathrm{v}_{\mathrm{ew}}$ is the specific volume of the water at the given temperature, and

$$
\mathrm{V}_{\mathrm{p}}=\mathrm{V}_{\mathrm{w}}+\mathrm{V}_{\mathrm{ow}}
$$

where $\mathrm{V}_{\mathrm{p}}$ is the pycnometer volume.

The substitution of Eq. [6] into Eq. [8] generates

$$
\mathrm{V}_{\mathrm{ow}}=\mathrm{V}_{\mathrm{P}}-\left(\mathrm{M}_{\mathrm{h}}-\mathrm{M}_{\mathrm{o}}\right) \cdot \mathrm{V}_{\mathrm{ew}}
$$

$\mathrm{V}_{\mathrm{g}}$ can then be measured with Eq. [10], that states the difference between $\mathrm{V}_{\mathrm{o}}$ and $\mathrm{V}_{\mathrm{ow}}$ :

$$
\mathrm{V}_{\mathrm{g}}=\mathrm{V}_{\mathrm{o}}-\mathrm{V}_{\mathrm{p}}+\left(\mathrm{M}_{\mathrm{h}}-\mathrm{M}_{\mathrm{o}}\right) \cdot \mathrm{V}_{\mathrm{e} w}
$$

Mass and volume determination. A balance (Sartorius, 1474) with an accuracy of $10^{-5} \mathrm{~kg}$ was used to measure the initial and final organ masses. For the differential immersion technique the initial and final volumes for use in Eq. [5] were measured with the same balance, according to the net impelling force that acts on the immersed organ inside a water reservoir, resting on top of the balance (Fig. I). The balance was zeroed with the aluminum weight hung from the support with the nylon thread without the organ.

Ripening. Changes in $\mathrm{V}$ during the ripening of mature-green 'Kada' tomato fruits at $23 \mathrm{C}$ held in plastic boxes covered by a PVC film were followed until they reached a complete red color. During storage the mass and the volume of the fruits were periodically measured and the variation of $\mathrm{V}_{\mathrm{g}}$ was estimated according to Eq. [5].

Compression. Mature-green 'Kada' tomato fruits were subjected to linear unidirectional deformations of $0,2.5,5.0,7.5$, and $10.0 \mathrm{~mm}$, with an Instron model 1130. Compression treatments were applied for $5 \mathrm{~min}$ and the changes of $\mathrm{V}_{\mathrm{g}}$ over time were recorded.

Infiltration. Validation assays with the use of infiltration were performed in sweetpotato roots (Ipomea batatas L. (Lam) cv. Coquinho) grown at CNPH/EMBRAPA, washed, and stored at $25 \mathrm{C}$ for $\approx 10$ days before use. For the assay, each root was divided in the middle to increase the rapidity of vacuum infiltration.

Changes in $\mathrm{V}_{\mathrm{g}}$ were induced by water infiltration under different vacuum treatments. For this purpose the roots were immersed in a desiccator filled with water, which was subsequently closed and connected to a vacuum pump with a pressure regulator. The 10-min vacuum treatments were adjusted to the following levels: $0.0,0.3,0.7$, and $1.0 \mathrm{P} / \mathrm{P}_{\mathrm{i}}$, where $\mathrm{P}_{\mathrm{f}}$ is the final absolute pressure and $\mathrm{P}_{\mathrm{i}}$ is the local initial absolute pressure $(93.0 \mathrm{KPa})$. Infiltration then occurred (after the vacuum release) during $15 \mathrm{~min}$ of additional water immersion.

The changes in $\mathrm{V}$ induced by vacuum infiltration $\left(\Delta \mathrm{V}_{\mathrm{o}}\right)$ were then measured by differential infiltration and compared with $\Delta \mathrm{V}_{\text {。 }}$ calculated by the gasometric technique of Calbo and Sommer (1987) and the pycnometric technique of Jensen et al. (1969). Measurements of $\mathrm{V}$ were made on ten replications, before and after the infiltration treatments.

Semi-pycnometric technique. Segments of 'Coquinho' sweetpotato tuberous roots, 'Kada' tomato fruits with near $50 \%$ of its external surface presenting red color, and green ' $\mathrm{CNPH}-208$ ' bell peppers were weighed and had volumes measured by water immersion using Archimedes' principle. The tissue was then homogenized with a blender and quantitatively transferred to a 250-ml pycnometer, which was submitted to successive evacuations with an oil vacuum pump to eliminate all air bubbles. At each evacuation step, air was introduced before the foam reached the 
pycnometer top. This repetitive process ended when additional vacuum exposures no longer caused air-bubble extraction or foam expansion. After that, the volume was carefully adjusted by placingdistilled water on the top of the denser layer of homogenate. The pycnometer lid was then inserted, and the pycnometric flask was externally towel-dried and weighed. The mass of the product $\left(\mathrm{M}_{\mathrm{o}}\right)$ and the mass of homogenate contained in the pycnometer $\left(\mathrm{M}_{\mathrm{h}}\right)$ were then used, along with $\mathrm{V}_{\mathrm{o}}$, to measure $\mathrm{V}_{\mathrm{g}}$ with Eq. [10].

Comparison among semi-pycnometry, differential mass-volume, infiltration, and the gasometric methods. The following working steps allowed the application of all these methods to each sample: 1) the mass-volume of the sample was measured; 2) $\mathrm{V}_{\mathrm{g}}$ was estimated with the technique of Calbo and Sommer (1987); 3) the tissue was infiltrated with water; 4) the final mass and volume were measured; and 5) the product volume without $\mathrm{V}_{\mathrm{g}}$ was measured by pycnometry [10].

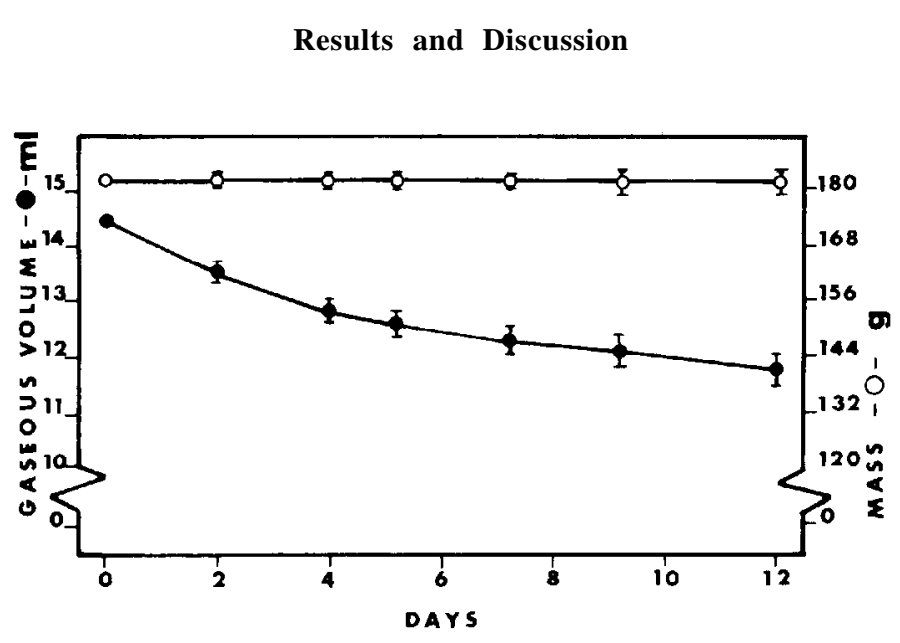

Fig. 2. Gas volume $\mathrm{V}_{\mathrm{g}}$ and the mass of mature-green 'Kada' tomato fruits during ripening, at $23 \mathrm{C}$ under a relative humidity of near $100 \%$. During the assay period the fruits became completely red. The initial $\mathrm{V}_{g}$, was estimated by the semipycnometric method, while the $\mathrm{V}_{\mathrm{g}}$ changes were followed with the differential mass-volume technique. Each point is the average of 40 replicates: bars represent standard error.
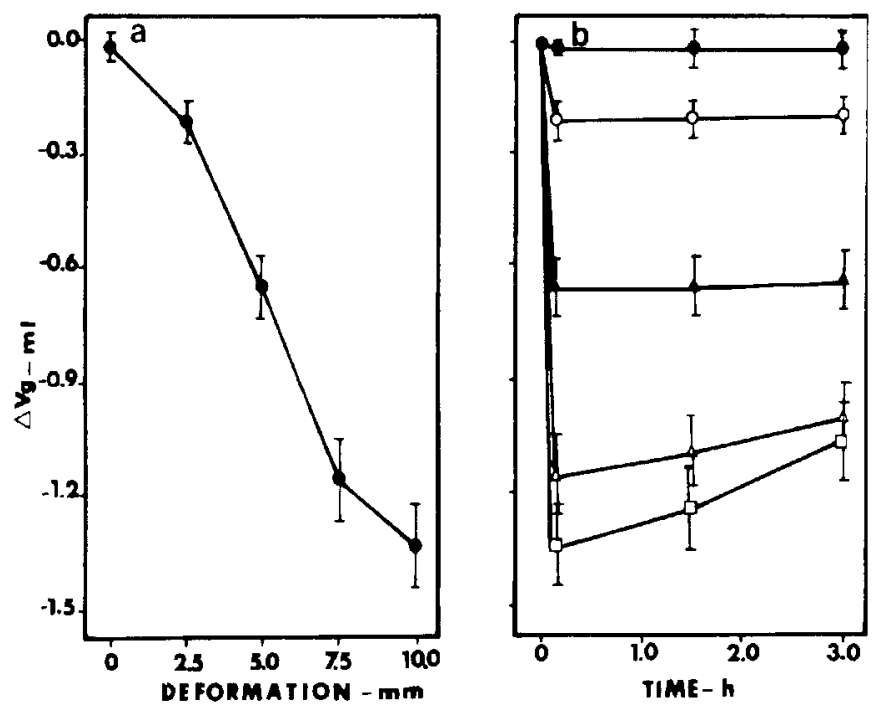

Fig. 3. A) Reduction of the gaseous volume $\Delta \mathrm{V}$, of $50 \%$ red 'Kada' tomato fruits subjected to different linear deformations during $5 \mathrm{~min}$. B) Subsequent gaseous volume regeneration in time. The applied linear deformations were $0(\bullet), 25(\mathrm{O})$, $50(\boldsymbol{\Delta}) .7 .5(\Delta)$. and $100(\square) \mathrm{mm}$. The fruits used had an average mass of $159.4 \mathrm{~g}$ and an initial gaseous volume of $12.6 \mathrm{ml}$. Bars represent standard error.
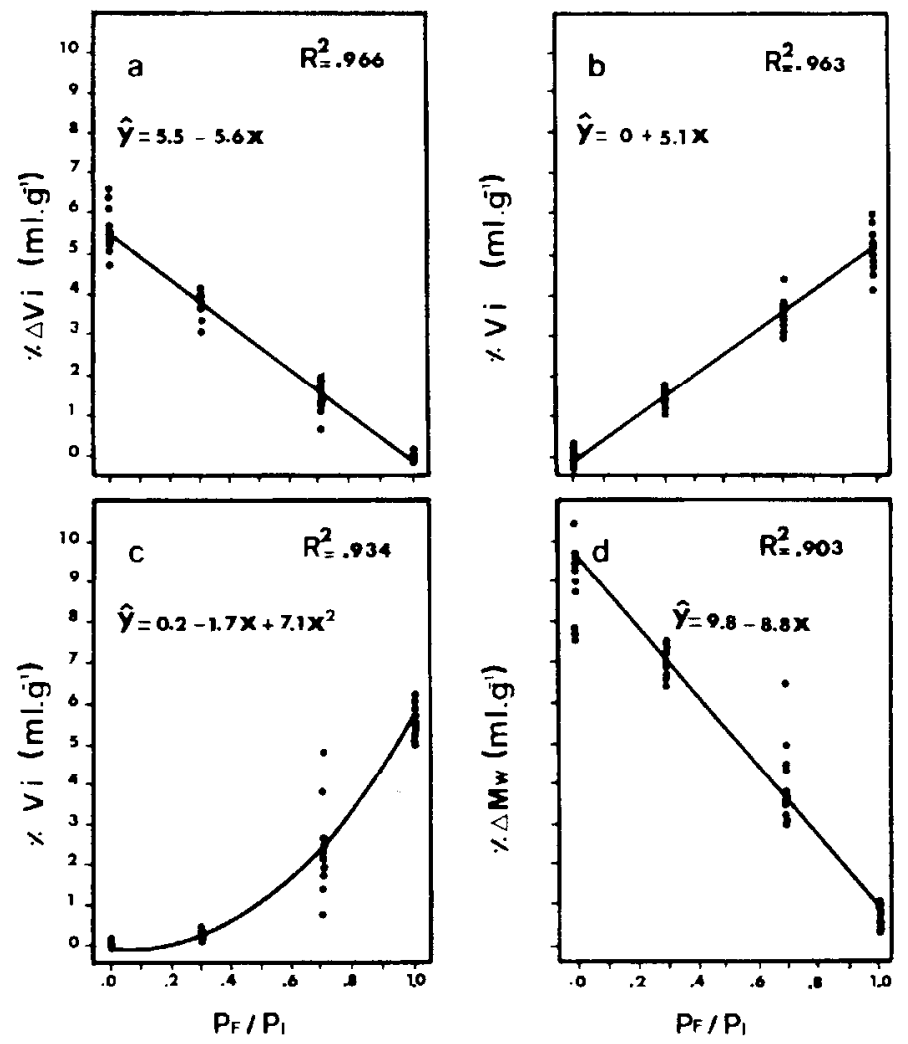

Fig. 4. Changes in intercellular gas volume (a-c) and mass (d) of sweet potato roots cv. Coquinho induced by water infiltration. wth use of the following levels of evacuation: $0.0,0.3,0.7$, and $1.0 \mathrm{P}_{f}, \mathrm{P}_{i}$, where $\mathrm{P}_{1}$ is the final pressure and $\mathrm{P}_{\mathrm{i}}$ is the initial pressure. (a) Variation of the gaseous volume $\left(\Delta \mathrm{V}_{\mathrm{s}}\right)$ was obtained with the differential immersion. (b) Gaseous volume $\left(\mathrm{V}_{\mathrm{g}}\right)$ obtained with the technique of Jensen et al. (1969). (c) Estimates of $\mathrm{V}_{\mathrm{g}}$ obtained with the technique of Calbo and Sommer (1987).

During ripening of the tomato fruit the differential massvolume method Eq. [5] shows that $\mathrm{V}_{\mathrm{g}}$ decreased smoothly in time (Fig. 2). from an initial absolute $\mathrm{V}_{\mathrm{g}}$ value of $14.5 \pm 1.1 \mathrm{ml}(\mathrm{n}=40)$ estimated with the semi-pycnometric technique. A nearly proportional $\mathrm{V}_{\mathrm{g}}$, reduction as a function of increasing levels of linear deformation (Fig. 3) was observed in mature-green fruits stressed during $5 \mathrm{~min}$. In these fruits the $\mathrm{V}_{\mathrm{g}}$ regeneration with time was very small (Fig. 3), which indicates that even small compressive stresses do cause a nearly irreversible strain in the tomato fruit $\mathrm{V}_{\mathrm{g}}$. These results about compression and ripening are new and would be difficult to demonstrate using standard destructive methods because the sample so is too large.

Comparison of the differential mass-volume and semipycnometric methods. The different levels of evacuation (0.0, 0.3, 0.7 , and $1.0 \mathrm{Pf} / \mathrm{Pi}$ ) applied to sweetpotato roots immersed in water, were efficient in inducing total and partial $\mathrm{V}_{\mathrm{g}}$ infiltration (Fig. 4). The differential mass-volume $\Delta \mathrm{V}_{\mathrm{g}}$ values presented in Fig. 4a. calculated with Eq. [5], were similar to those (Fig. 4b) obtained with the adaptation of the pycnometric technique of Jensen et al. (1960).

Figure $4 \mathrm{c}$ presents results obtained with the use of the gasometric method of Calbo and Sommer (1987), where $\mathrm{V}_{\mathrm{g}}$ is calculated according to the water volume displaced $\left(\mathrm{V}_{\mathrm{m}}\right)$ by the expansion of the air volume previously contained inside the organ. This gasometric technique yields smaller values of $\mathrm{V}_{\mathrm{g}}$ than the technique herein proposed and the technique of Jensen et al. (1969) at the two intermediate levels of evacuation. Underestimation in 
these intermediate levels of evacuation was possibly due to restrictions for gas expansion in the previously flooded $\mathrm{V}_{\mathrm{g}}$.

Figure $4 \mathrm{~d}$ shows that the infiltration caused a mass increase about twice as large as expected according to pycnometric estimates of $\Delta \mathrm{V}_{\mathrm{g}}$. Despite this fact, the infiltration technique has been used to estimate $\mathrm{V}_{\mathrm{g}}$ in leaves without considering the protoplast water absorption. Smith and Heuer (1981) tried to improve the infiltration technique using successive evacuations (two or three) in leaves immersed in a solution with chemical potential similar to cellular water potential, aiming to avoid water absorption by elimination of the chemical potential gradient that drives cellwater absorption. Even this technique did not consider properly the water absorbed by the cells in bulky organs for measurement of $\mathrm{V}_{\mathrm{g}}$. To clarify this point consider two cells inside an organ, one cell at the surface and the other in the center, infiltrated with a solution of chemical potential equal to the organ average water potential:

A) The cell near the surface, close to the infiltrating solution, will have the apoplast water potential $\left(\psi_{\text {wa }}\right)$ equal to the symplast water potential $\left(\psi_{w}\right.$, Eq. [12]).

$$
\psi_{\mathrm{wa}}=\psi_{\mathrm{w}}=\psi_{\mathrm{sa}}-\mathrm{P}
$$

The pressure component $\mathrm{P}$ in Eq. [12] became equal to the hydrostatic pressure of the infiltrating solution as $\mathrm{V}$ is replaced by water. Accordingly, $\mathrm{P}$ could be assumed negligible, while the apoplast osmotic potential $\left(\psi_{\mathrm{sa}}\right)$ would be equal to the organ water potential $\left(\psi_{w}\right)$, and equal to the chemical potential of the infiltrating solution ( $\psi \mathrm{q})$, as presented by Eq. [12].

$$
\psi_{\mathrm{w}}=\psi_{\mathrm{sa}}=\psi_{\mathrm{wa}}=\psi_{\mathrm{q}}
$$

B) For a cell in the center of the organ, Eq. [11] remains valid, but $\psi_{\mathrm{sa}}$ cannot be considered equal to the chemical potential of the infiltrating solution $\left(\psi_{q}\right)$. The resulting $\psi_{\mathrm{sa}}$ after infiltration, however, could be estimated using Eq. [13], if water absorption by the cells is disregarded.

$$
\psi_{\mathrm{sa}}=\left(\psi_{\text {sai }} \cdot \mathrm{Va}_{\mathrm{p}}+\psi_{\mathrm{q}} \cdot \mathrm{V}_{\text {inf }}\right) /\left(\mathrm{V}_{\mathrm{ap}}+\mathrm{V}_{\text {inf }}\right)
$$

where $\psi_{\text {sai }}$ is the initial osmotic potential of the apoplastic solution, $\mathrm{V}_{\text {ap }}$ is the apoplast volume, and $\mathrm{V}_{\text {inf }}$ is the volume of solution that has infiltrated the organ.

Since the apoplast volume is a considerable fraction of the organ volume (Boyer, 1967; Shayo-Ngowi and Campbell, 1979), the two following points should be considered for using Eq. [13]: a) the diffusion between the infiltrating solution in the intercellular spaces and the cell wall sap solution is very fast, but the expected progressive dilution that should occur as the infiltrating solution penetrates the organ is disregarded, and only the average dilution effect is considered for simplicity; b) diffusion in the liquid phase of order of $10^{-9} \mathrm{~m}^{2} \cdot \mathrm{s}^{-1}$ (Armstrong, 1979) would be far too small to allow a concentration equilibrium between a point in the center of the organ and a point on the organs' surface during the assay period.

If initially the water potential in the apoplast was in near equilibrium with the water potential in the symplast [11], then even infiltration with a solution of chemical potential $\psi \mathrm{q}=\psi \mathrm{w}$ changes the apoplast water potential, since the component $\mathrm{P}$ is nearly suppressed by the infiltration. Under these assumptions Eq. [13] represents the final sap chemical potential. The consequence of these effects is that the water potential in the symplast becomes lower than the water potential in the apoplast, because the solute concentration in the apoplast is usually low (Campbell, et al., 1979;

Table 1. Parameters, formulas, data, and evaluation of the semi-pycnometric technique to measure $\mathrm{V}_{\mathrm{g}}$, in comparison to the gasometric technique of Calbo and Sommer (1987), the differential mass-volume method and the infiltration technique without correction for cellular water absorption applied to the same samples, where $n$ is the number of replicates. $\mathrm{M}_{\mathrm{i}}$ is the initial mass, $\mathrm{M}_{\mathrm{f}}$ is the final mass, $\mathrm{V}_{\mathrm{oi}}$ is the initial organ volume, $\mathrm{V}_{\text {of }}$ is

\begin{tabular}{|c|c|c|c|c|c|c|c|c|c|c|c|c|c|c|}
\hline \multirow[b]{2}{*}{$\mathbf{n}$} & \multicolumn{10}{|c|}{ Measurement } & \multirow{2}{*}{$\begin{array}{c}\mathrm{SP}^{z} \\
\mathrm{~V}_{\mathrm{g}} \\
\mathrm{mL}\end{array}$} & \multirow{2}{*}{$\begin{array}{c}\mathrm{G}^{\mathrm{y}} \\
\mathrm{V}_{\mathrm{g}} \\
\mathrm{mL}\end{array}$} & \multirow{2}{*}{$\begin{array}{c}\mathrm{M}-\mathrm{V}^{\mathrm{x}} \\
\Delta \mathrm{V}_{\mathrm{g}} \\
\mathrm{mL}\end{array}$} & \multirow{2}{*}{$\begin{array}{c}\mathrm{I}^{\mathrm{w}} \\
\mathrm{V}_{\mathrm{g}} \\
\mathrm{mL}\end{array}$} \\
\hline & $\begin{array}{c}\mathrm{M}_{\mathrm{i}} \\
\mathrm{g}\end{array}$ & $\begin{array}{c}\mathrm{M}_{\mathrm{f}} \\
\mathrm{g}\end{array}$ & $\begin{array}{l}\mathrm{V}_{\mathrm{oi}} \\
\mathrm{mL}\end{array}$ & $\begin{array}{l}\mathrm{V}_{\text {of }} \\
\mathrm{mL}\end{array}$ & $\begin{array}{c}\mathrm{M}_{\mathrm{h}} \\
\mathrm{g}\end{array}$ & $\begin{array}{l}\mathrm{V}_{\mathrm{p}} \\
\mathrm{mL}\end{array}$ & $\begin{array}{l}\mathrm{V}_{\mathrm{m}} \\
\mathrm{mL}\end{array}$ & $\begin{array}{c}P_{i} \\
\mathrm{kPa}\end{array}$ & $\begin{array}{c}\mathrm{P}_{\mathrm{f}} \\
\mathrm{kPa}\end{array}$ & $\underset{\mathrm{kPa}}{\mathrm{P}_{\mathrm{v}}}$ & & & & \\
\hline \multicolumn{15}{|c|}{ Bell pepper } \\
\hline 1 & 65.21 & 150.75 & 145.40 & 154.91 & 884.35 & 882.85 & 15.2 & 93.0 & 72.0 & 3.13 & 81.69 & 50.04 & -76.03 & 95.54 \\
\hline 2 & 88.25 & 186.65 & 177.20 & 189.28 & 885.10 & 882.90 & 15.0 & 93.0 & 73.9 & 3.13 & 89.48 & 65.82 & -86.32 & 98.40 \\
\hline 3 & 96.52 & 188.47 & 183.75 & 192.72 & 884.35 & 882.90 & 15.5 & 93.0 & 73.9 & 3.13 & 89.48 & 57.68 & -82.98 & 91.95 \\
\hline 4 & 66.56 & 147.98 & 146.26 & 151.59 & 824.35 & 882.85 & 14.3 & 93.0 & 72.6 & 3.13 & 81.20 & 48.72 & -76.09 & 81.42 \\
\hline 5 & 81.20 & 161.20 & 160.80 & 165.30 & 884.50 & 882.85 & 15.0 & 93.0 & 72.6 & 3.13 & 81.25 & 51.10 & -75.50 & 80.00 \\
\hline \multicolumn{15}{|c|}{ Tomato } \\
\hline 1 & 131.25 & 143.45 & 137.37 & 144.46 & 885.70 & 885.85 & 6.0 & 93.0 & 52.6 & 3.13 & 8.32 & 7.35 & -5.11 & 12.20 \\
\hline 2 & 158.62 & 186.36 & 174.89 & 188.90 & 885.05 & 882.85 & 7.4 & 93.0 & 52.6 & 3.13 & 19.32 & 9.07 & -13.73 & 27.74 \\
\hline 3 & 144.77 & 158.57 & 153.00 & 157.90 & 885.85 & 882.80 & 6.0 & 93.0 & 52.6 & 3.13 & 10.38 & 7.35 & -8.90 & 13.80 \\
\hline 4 & 176.94 & 205.15 & 185.16 & 200.52 & 885.70 & 882.90 & 12.2 & 93.0 & 34.4 & 3.13 & 11.02 & 6.53 & -7.04 & 28.21 \\
\hline 5 & 152.64 & 170.43 & 162.37 & 171.74 & 885.35 & 882.85 & 6.5 & 93.0 & 52.6 & 3.13 & 12.23 & 7.96 & -8.42 & 17.79 \\
\hline \multicolumn{15}{|c|}{ Sweetpotato } \\
\hline 1 & 97.54 & 113.92 & 91.92 & 104.06 & 893.15 & 882.80 & 6.5 & 93.0 & 39.4 & 3.13 & 4.58 & 4.40 & -4.24 & 16.38 \\
\hline 2 & 116.77 & 148.07 & 109.03 & 133.66 & 897.50 & 882.80 & 8.9 & 93.0 & 39.4 & 3.13 & 6.91 & 6.03 & 6.67 & 31.30 \\
\hline 3 & 81.91 & 98.88 & 76.53 & 89.77 & 892.30 & 882.85 & 5.5 & 93.0 & 39.4 & 3.13 & 4.07 & 5.73 & 4.33 & 17.97 \\
\hline 4 & 114.89 & 134.18 & 109.77 & 124.26 & 892.57 & 882.85 & 6.4 & 93.0 & 39.4 & 3.13 & 4.60 & 4.33 & 4.80 & 19.29 \\
\hline 5 & 105.29 & 131.31 & 98.22 & 120.40 & 894.42 & 887.85 & 6.0 & 93.0 & 39.4 & 3.13 & 4.50 & 4.06 & 4.37 & 17.81 \\
\hline
\end{tabular}
the infiltrated organ final volume, $\mathrm{M}_{\mathrm{h}}$ is the homogenate mass contained inside the pycnometer, $\mathrm{V}_{\mathrm{p}}$ the pycnometer volume, $\mathrm{V}_{\mathrm{m}}$ is the gas volume dislocated in the-measuring pipette when the pressure in the fruit was reduced from an initial value $\mathrm{P}_{\mathrm{i}}$ to a final value $\mathrm{P}_{\mathrm{f}}$ under avapor pressure $\mathrm{P}_{\mathrm{v}}$.

${ }^{\bar{S}} \mathrm{SP}=$ semi-pycnometry. $\mathrm{V}_{\mathrm{g}}=\mathrm{V}_{\mathrm{o}}-\mathrm{V}_{\mathrm{P}}+\left(\mathrm{M}_{\mathrm{h}}-\mathrm{M}_{\mathrm{o}}\right) \mathrm{V}_{\mathrm{e}}$

${ }^{\mathrm{y}} \mathrm{G}=$ gasometry. $\mathrm{V}_{\mathrm{g}}=\mathrm{V}_{\mathrm{m}}\left(\mathrm{P}_{\mathrm{f}}-\mathrm{P}_{\mathrm{v}}\right) /\left(\mathrm{P}_{\mathrm{f}}-\mathrm{P}_{\mathrm{i}}\right)$

${ }^{\mathrm{x}} \mathrm{M}-\mathrm{V}=$ differential mass-volume. $\Delta \mathrm{V}_{\mathrm{g}}=\Delta \mathrm{V}_{\mathrm{o}}-\Delta \mathrm{M} \mathrm{V}_{\mathrm{ew}}$

"I = infiltration. $\mathrm{V}_{\mathrm{g}}=\left(\mathrm{M}_{\mathrm{f}}-\mathrm{M}_{\mathrm{i}}\right) \mathrm{V}_{\mathrm{ew}}$ 
Cosgrove and Cleland, 1983; Meizer and Moore, 1988). Consequently, water absorption occurs during infiltration, even when $\psi_{q}$ is equal to $\psi_{w}$, as in the infiltration method of Smith and Heuer (1981) for $\mathrm{V}_{\mathrm{g}}$ measurement.

In the specific case of infiltration at $\left(\mathrm{P}_{\mathrm{f}} / \mathrm{P}_{\mathrm{i}}=0\right)$, the proposed differential technique becomes mathematically equivalent to the infiltration method of Kushmann and Pope (1968), that is not subject to errors due to cellular water absorption as discussed.

Semi-pycnometric technique. Eq. [14] used in the pycnometric method (Jensen et al., 1969) to measure $\mathrm{V}_{\mathrm{g}}$ in small roots could be interpreted as the difference between the organ total volume volume $\left(\mathrm{V}_{\mathrm{o}}\right)$ and the organ volume without its gaseous volume $\left(\mathrm{V}_{\text {ow }}\right)$.

$$
\mathrm{V}_{\mathrm{g}}=\left(\mathrm{M}_{\mathrm{h}}-\mathrm{M}_{\mathrm{r}+\mathrm{w}}\right) \cdot \mathrm{V}_{\mathrm{ew}}=\mathrm{V}_{\mathrm{o}}-\mathrm{V}_{\mathrm{ow}}
$$

where $\mathrm{M}_{\mathrm{h}}$ is the mass of the pycnometer with the homogenized roots (without air bubbles) and $\mathrm{M}_{\mathrm{r}+\mathrm{w}}$ is the mass of the pycnometer containing the roots and the necessary amount of water mass to complete its volume.

In the semi-pycnometric technique, the organ volume $\mathrm{V}_{\mathrm{o}}$ is estimated by water immersion (Fig. 1) and the pycnometer is only used to measure $\mathrm{V}_{\text {ow }}$ the organ volume without $\mathrm{V}_{\mathrm{g}}$, after the homogenization and repeated vacuum exposures to eliminate all gas bubbles. The semi-pycnometry is faster than pycnometry and allows the measurement of $\mathrm{V}_{\mathrm{g}}$ in organs with internal cavities, because $\mathrm{V}_{0}$ can be measured without sectioning of the samples.

Table 1 presents $\mathrm{V}_{\mathrm{g}}$ estimates for bell pepper, tomato, and sweetpotato root segments using the semi-pycnometric method in comparison with the method of Calbo and Sommer (1987), the differential mass-volume technique, and the infiltration method without correction for the cellular water absorption applied separately to each sample.

The semi-pycnometric method always generated results similar to the differential mass-volume method. The infiltration technique, without correction for cellular water absorption, greatly overestimated $\mathrm{V}_{\mathrm{g}}$ in sweetpotatoes, while in bell peppers and tomatoes the loss of water through cracks formed in the infiltrated tissues and difficulty in obtaining a complete infiltration caused underestimation of $\mathrm{V}_{\mathrm{g}}$. The semi-pycnometric technique is not sensitive to the same sources of error that affect the infiltration method because it does not require infiltration, only the pycnometric homogenate mass [14]. The Calbo and Sommer (1987) technique generates satisfactory values for organs with cavities and large $\mathrm{V}_{\mathrm{g}}$ but it overestimates $\mathrm{V}_{\mathrm{g}}$ for compact organs with small $\mathrm{V}_{\mathrm{g}}$, where the solubility of the gases in water becomes important.

General Remarks. With the proposed modifications, the estimates of $\mathrm{V}_{\mathrm{g}}$ can now be made in a larger range of studies that can involve small changes of $\mathrm{V}_{\mathrm{g}}$ even in succulent organs or organs with internal cavities. The differential mass-volume method proved to be valuable for studies on $\mathrm{V}_{\mathrm{g}}$ changes in processes in which it would be impractical to use previously described methods, leading us to believe that it will be valuable for studies about the genesis, nature, and stability of the intercellular air volumes in plants.

\section{Literature Cited}

Armstrong, W. 1979. Aeration in higher plants. Adv. Bot. Res. 7:225-232. Baumann, H. and I. Henze. 1983. Intercellular space volume of fruit. Acta
Hort. 138:107-111.

Boyer, J. 1967. Manic potentials of leaves. Plant Physiol. 42:213-217.

Burton, W.G. and W.T. Spragg. 1950. A note on the intercellular spaces of potato tuber. New Phytol. 49:8-10.

Byott, G.S. 1976. Leaf air space systems in $\mathrm{C}_{3}$ and $\mathrm{C}_{4}$ species. New Phytol. 76:295-299

Calbo, A.G. and Sommer, N.F. 1987. Intercellular volume and resistance to mass air flow of fruits and vegetables. J. Amer. Soc. Hort. Sci. 112:131-134.

Cameron, A.C. and S.F. Yang. 1982. A simple method for the determination of gas diffusion in plant organs. Plant Physiol. 70:21-23.

Campbell, R. and M.C. Drew. 1983. Electron microscopy of gas space (aerenchyma) formation in adventitious roots of Zea mays $\mathrm{L}$. subjected to oxygen shortage. Planta 157:350-357.

Campbell, G.S., R.I. Papendick, E. Rabie, and A.I. Shayo Ngowi. 1979. A comparison of osmotic potential, elastic modulus, and apoplastic water in leaves of dryland winter wheat. Agron. J. 71:31-36.

Cosgrove, D.J. and R.E. Cleland. 1983. Solutes in the free space of growing stem tissues. Plant Physiol. 72:326-31.

Czersky, J. 1964. Gasometric method of volume determination of intercellular space in plant tissue. Soc. Bot. Pol. 33:247-262.

De Chalain, T.M.B. and P. Berjak. 1979. Cell death as a functional event in the development of leaf intercellular space in Avicennia marina. New Phytol. 83: 147-155.

Dupler, A.W. 1921. The air chamber of Reboulia hemispherica. Bul. Torrey Bot. Club 48:241-252.

Evans, A.W. 1918. The air chamber of Orimaldia fragrans. Bul. Torrey Bot. Club 45:235-251.

Hirsh, P. E. 1910. The development of air chambers in the Ricciaceae. Bul. Tor. Bot. Club 37:73-77.

Jeffree, C.E., J.E. Dale, and S.C. Fry. 1986. The genesis of intercellular spaces in developing leaves of Phaseolus vulgaris L. Protoplasma 132:90-98.

Jensen, CR., R.J. Luxmore, SD. Van Grundy, and L.H. Stolzy. 1969. Root air space measure by a pycnometer method. Agron. J. 61:474-475.

Kawase, M. 1981. Anatomical and morphological adaptation of plants to waterlogging. HortScience 16:8-12.

Kolloffel, C. and P.W.T. Lissen. 1985. The formation of intercellular space in the cotyledons of developing and germinating pea seeds. Protoplasma 120: 12-19.

Kushmann, L. I. and D.T. Pope. 1968. Procedure for determining intercellular space of roots and specific gravity of sweetpotato root tissue. HortScience 3:44-45.

Laan, P., M.J. Berrevets, S. Lythe, W. Armstrong, and W.P.M. Blom. 1989. Morphology and aerenchyma formation as indicators of the floodtolerance of Rumex species. J. Ecol. 77:693-703.

Magness, J.R. 1922. Composition of gases in intercellular spaces of apples and potatoes. Bot. Gaz. 13:349-357.

Meizer, F.C. and P.H. Moore. 1988. Effect of apoplastic solutes on water potential in elongating sugarcane leaves. Plant Physiol. 86:873-879.

Raskin, I. 1983. A method for measuring leaf volume, density, thickness, and internal gas volume. HortScience 18:698-699.

Shayo-Ngowi, A. and G.S Campbell. 1980. Measurement of matric potential in plant tissue with a hydraulic press. Agron. J. 72:567-568.

Sifton, H.V. 1945. Air space tissue in plants. Bot. Rev. 11:108-143.

Sifton, H.V. 1957. Air space tissue in plants. Bot. Rev. 23:303-312.

Smith, J.A. and S. Heuer. 1981. Determination of the volume of intercellular spaces in leaves and some values for CAM plants. Ann. Bot. 48:915-917.

Spector, W.S. 1956. Handbook of biological data. Technical Report of the Wright Air Development Center, 56:273.

Yu, P.T., L.H. Stolzy, and I. Letey. 1969. Survival of plants under prolonged flooded conditions. Agron. J. 61:844-847. 